\title{
The impact of a school-based nutrition education intervention on dietary intake and cognitive and attitudinal variables relating to fruits and vegetables
}

\author{
AS Anderson ${ }^{1, *}$, LEG Porteous ${ }^{1}$, E Foster ${ }^{2}$, C Higgins $^{3}, M$ Stead $^{4}, M$ Hetherington $^{5}$, \\ $\mathrm{M}-\mathrm{A} \mathrm{Ha}{ }^{1}$ and AJ Adamson ${ }^{2}$ \\ ${ }^{1}$ Centre for Public Health Nutrition Research, Ninewells Medical School, University of Dundee, Dundee DD1 9SY, \\ UK: ${ }^{2}$ Human Nutrition Research Centre, School of Clinical Medical Sciences, University of Newcastle, UK: \\ ${ }^{3}$ Department of Psychology, University of Dundee, UK: ${ }^{4}$ Centre for Social Marketing, University of Strathclyde, \\ UK: ${ }^{5}$ School of Psychology, University of Liverpool, UK
}

Submitted 28 August 2003: Accepted 8 September 2004

\begin{abstract}
Objective: To assess the impact of a school-based nutrition education intervention aimed at increasing the consumption of fruits and vegetables.

Design: The intervention programme increased the provision of fruits and vegetables in schools and provided a range of point-of-purchase marketing materials, newsletters for children and parents, and teacher information. Curriculum materials at age 6-7 and 10-11 years were also developed and utilised. Evaluation was undertaken with groups of younger (aged 6-7 years) and older (aged 10-11 years) children. Methods included 3-day dietary records with interview and cognitive and attitudinal measures at baseline, with follow-up at 9 months, in intervention and control schools.

Setting: The work was undertaken in primary schools in Dundee, Scotland.

Subjects: Subjects comprised 511 children in two intervention schools with a further 464 children from two schools acting as controls.

Results: Children $(n=64)$ in the intervention schools had an average increase in fruit intake $\left(133 \pm 1.9\right.$ to $\left.183 \pm 17.0 \mathrm{~g} \mathrm{day}^{-1}\right)$ that was significantly $(P<0.05)$ greater than the increase $\left(100 \pm 11.7\right.$ to $\left.107 \pm 14.2 \mathrm{~g} \mathrm{day}^{-1}\right)$ estimated in children $(n=65)$ in control schools. No other changes in food or nutrient intake were detected. Increases in scores for variables relating to knowledge about fruits and vegetables and subjective norms were also greater in the intervention than in the control group, although taste preferences for fruits and vegetables were unchanged.

Conclusions: It is concluded that a whole school approach to increasing intakes of fruits and vegetables has a modest but significant effect on cognitive and attitudinal variables and on fruit intake.
\end{abstract}

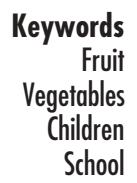

It is widely accepted that high intakes of fruits and vegetables $(\mathrm{F} \& \mathrm{~V})$ are associated with lower rates of chronic diet-related diseases including cardiovascular disease and certain cancers $^{1-3}$. Current dietary recommendations ${ }^{4}$ promote a minimum intake of $400 \mathrm{~g} \mathrm{F \& V}$ daily, and this has generally been translated into 5 portions of approximately $80 \mathrm{~g}$. A number of countries have now adopted a 'five-a-day' message, including the USA, where the National Cancer Institute initiated a national '5-A-Day for Better Health Programme' in $1991^{5}$, and more recently England ${ }^{6}$.

In the UK, recent surveys have reported low intakes of $\mathrm{F} \& \mathrm{~V}$ throughout the life span. In children aged $4-18$ years, a recent study reported that more than half of 845 children surveyed in a 7-day period had not eaten any citrus fruit, green vegetables or tomatoes ${ }^{7}$. Boys' intakes of F\&V were notably poor. Of all the vegetable categories recorded by boys, only peas, baked beans and cooked carrots had been consumed by more than half the sample.

Dietary habits in childhood will impact on growth, development and disease risk throughout life ${ }^{8}$. However, it is recognised that establishing healthy eating habits in children is a major challenge to health promotion. It is likely that children's eating habits are still being developed during early school years and this provides an important opportunity to target F\&V consumption. Studies that have examined the principles of learning theory reveal the power and significance of associative conditioning, exposure, experience and positive reinforcement ${ }^{9}$. Recent 
work ${ }^{10}$ highlights the importance of 'liking' as a predictor of $\mathrm{F} \& \mathrm{~V}$ intake in children.

School-based interventions have shown some success in promoting appropriate dietary behaviours in children, notably with multi-strategy interventions ${ }^{11}$. The principle of the 'health-promoting school' ${ }^{12}$ offers an opportunity to incorporate curriculum approaches, food service settings, and parental and community networks for health benefits. The aim of the present work was to assess the impact of a whole school intervention on cognitive and attitudinal variables relating to $\mathrm{F} \& \mathrm{~V}$ and estimated dietary intake.

\section{Methods}

\section{Overview}

A whole school intervention was implemented from October 1999 to June 2000 in two junior schools in Dundee, Scotland. Its impact was assessed by comparing changes in knowledge, beliefs and attitudes towards F\&V and dietary intake. These assessments were made at baseline (T1) (e.g. during September before the intervention commenced) with a follow-up (T2) which occurred 9 months after baseline (e.g. during June, after implementation of the intervention was complete). The assessments were made in groups of children aged 6-7 and 10-11 years.

\section{Background data}

Schools were selected following discussions with the local education authority, which advised on 12 schools not currently involved in research studies. Four schools agreed to participate and these were paired for similarity of social background and size; each pair was then randomly assigned to the intervention or control group. The school provided information on school roll and other relevant social characteristics. Data on age and postal codes were obtained from children.

\section{Intervention programme}

The intervention programme provided increased provision of F\&V in schools (tuck shops and school lunches), tasting opportunities, a range of point-of-purchase marketing (posters and quizzes), newsletters for children and parents, and teacher information sessions (delivered in school assemblies, training sessions and classroom presentations). Curriculum materials at age 6-7 and 10-11 years (largely focusing on practical food preparation and tasting, promoted through hands-on activities, written work, videos, self-monitoring materials and story books) were also utilised. Table 1 provides an overview of the programme. A graphics package was developed using cartoon characters (The Bash Street Kids ${ }^{\circledR}$, DC Thomson \& Co. Ltd) which were used as a theme in the communication and promotional materials. Full programme details are available elsewhere ${ }^{13}$.

\section{Cognitive and attitudinal assessments to FEV}

Age-appropriate assessments were developed to examine beliefs, attitudes and knowledge (related to F\&V) based on the Theory of Planned Behaviour ${ }^{14}$. The assessments used age-appropriate language and involved a combination of card-sort techniques and short interview questions (Table 2). Most assessments focused on 12 core foods/drinks (Table 3). In addition, a tray containing small samples of these items was offered to the children for tasting. Core items, representing high and low fruit and vegetable content, were selected as familiar to children. The children were asked to taste and then rate their liking on a 5-point hedonic scale adapted from Birch et al. ${ }^{15}$ and to rank these foods in order of preference.

Table 1 Intervention programme

\begin{tabular}{ll}
\hline Area & \\
\hline Food provision within the school & Fruit sold daily in the tuck shop \\
& School dinners \\
& $-\quad$ Vegetable soup or starter once a week \\
& $-\quad$ Weekly choice of a fruit-based pudding \\
& A news sheet suitable for 11-year-olds \\
Communications & School assembly \\
& Class presentation on portion size \\
& Demonstration to teachers on practical F\&V activities which could be reproduced in a class \\
& room to encourage the children to taste and enjoy F\&V \\
& Topic work using F\&V for 'myself' and 'senses' projects as part of the Environmental Studies \\
Learning materials & curriculum \\
& Lunchbox topic for infants \\
Lunchbox topic for upper primary & Parent helpers in the tuck shop \\
Parent newsletter
\end{tabular}

F\&V - fruits and vegetables. 
Table 2 Details of attitudinal assessments

\begin{tabular}{|c|c|c|}
\hline Description & Construct & Purpose of measure \\
\hline \multirow{2}{*}{$\begin{array}{l}\text { Relevant background } \\
\text { information }\end{array}$} & & Name, date of birth \\
\hline & $\begin{array}{l}\text { Taste experience } \\
\text { Access to } \mathrm{F} \& \mathrm{~V} \text { in home }\end{array}$ & $\begin{array}{l}\text { Previous experience of tasting the foods discussed throughout the test } \\
\text { Access to fruits, vegetables, sweets, biscuits and crisps in the home }\end{array}$ \\
\hline \multirow[t]{7}{*}{$\begin{array}{l}\text { Knowledge and } \\
\text { behavioural intention }\end{array}$} & $\begin{array}{l}\text { Understanding of the } \\
\text { concept 'healthy' } \\
\text { Categorisation skills }\end{array}$ & $\begin{array}{l}\text { Children were asked if they knew the word 'healthy' and to give examples } \\
\text { of foods which were 'healthy' or 'less healthy' } \\
\text { A card-sort technique which assessed each child's ability to categorise } \\
\text { F\&V accurately }\end{array}$ \\
\hline & $\begin{array}{l}\text { Knowledge of F\&V } \\
\text { content of foods }\end{array}$ & $\begin{array}{l}\text { Card-sort technique. Children placed photographs of the target foods into } \\
\text { one of three response categories: 'lots of F\&V', 'some F\&V', 'no F\&V' }\end{array}$ \\
\hline & Subjective norms & $\begin{array}{l}\text { Card-sort technique. Children placed cards in one of two response } \\
\text { categories according to perceived social pressure from school nurse to } \\
\text { 'eat less' or 'eat more' }\end{array}$ \\
\hline & Paired choices & $\begin{array}{l}\text { Task requiring children to choose the healthier of two options from core } \\
\text { foods assessing child's knowledge of healthier food choices }\end{array}$ \\
\hline & $\begin{array}{l}\text { Knowledge of relationship } \\
\text { between diet and heart } \\
\text { disease }\end{array}$ & $\begin{array}{l}\text { Questions examining children's knowledge of the relationship } \\
\text { between diet and heart disease }\end{array}$ \\
\hline & Behavioural intention & $\begin{array}{l}\text { Card-sort technique requiring children to sort foods into categories } \\
\text { according to their intention to eat more or less of the core foods }\end{array}$ \\
\hline & $\begin{array}{l}\text { Knowledge of ' } 5 \text {-a-day' } \\
\text { (10-11-year-old } \\
\text { pupils only) }\end{array}$ & $\begin{array}{l}\text { Card-sort technique. Children were required to select } 5 \text { portions of F\&V } \\
\text { from nine photographs of } F \& V^{8} \text { and nine other foods taken from the } \\
\text { target foods }\end{array}$ \\
\hline \multirow[t]{2}{*}{$\begin{array}{l}\text { Measures for recording } \\
\text { food preferences }\end{array}$} & $\begin{array}{l}\text { Taste preferences } \\
\text { (facial hedonic scales) }\end{array}$ & $\begin{array}{l}\text { 5-point facial hedonic scale on which children assigned a pleasantness } \\
\text { value after tasting and ranked order of preference }\end{array}$ \\
\hline & $\begin{array}{l}\text { Taste preferences } \\
\quad \text { (ranked) }\end{array}$ & $\begin{array}{l}\text { Card-sort technique. Children selected their five favourite foods from all } \\
\text { target foods and ranked these five in order of preference }\end{array}$ \\
\hline
\end{tabular}

F\&V - fruits and vegetables.

\section{Assessment of food and nutrient intakes}

Since the intervention was school-based, all dietary assessments were made on school days only to facilitate dietary recalls in these young children.

At baseline and follow-up, children completed a 3-day food diary accompanied by an interview to ascertain all foods eaten and portion sizes. The younger age group (6- to 7-year-olds) was interviewed on a daily basis while the older children (10- to 11-year-olds) were interviewed only once, at the end of the recording period. Lay assistants, who received one week's training in the methodology, conducted the interviews.

Table 3 Target foods

\begin{tabular}{ll}
\hline $\begin{array}{l}\text { Core foods used for } \\
\text { taste preferences } \\
\text { and card-sort tasks }\end{array}$ & $\begin{array}{l}\text { Additional foods used for ranked } \\
\text { preferences and card-sort tasks }\end{array}$ \\
\hline $\begin{array}{l}\text { Fresh orange juice } \\
\text { Carrots }\end{array}$ & $\begin{array}{l}\text { Cherries } \\
\text { Fruit salad }\end{array}$ \\
$\begin{array}{l}\text { Tomatoes } \\
\text { Grapes }\end{array}$ & $\begin{array}{l}\text { Raisins } \\
\text { Bananas }\end{array}$ \\
$\begin{array}{l}\text { Melon } \\
\text { Apples }\end{array}$ & Pears \\
Cheese-filled biscuits & Chips \\
Chocolate buttons & Burgers \\
Tomato-flavoured crisps & Doughnuts \\
Apple pie & Chocolate biscuits \\
Cola drink & Ice cream \\
Jelly sweets & \\
\hline
\end{tabular}

Food diaries were included in the nutrient analysis if the child had completed the 3-day diaries at both time points. Foods were coded using standard food tables ${ }^{16-25}$. Food codes and weights were entered in a nutrient analysis database and subjected to both automated and manual quality control checks. Mean daily intakes were calculated from the 3-day totals and change from T1 to T2 was calculated. Analyses were carried out on the dataset as a whole and, following the protocol for the National Diet and Nutrition Survey ${ }^{7}$, no exclusions for under- or overreporting were made.

\section{Statistical analysis}

Univariate analysis of variance was used to identify statistically significant differences between the control and intervention groups over time.

\section{Results}

A description of the participating schools is presented in Table 4. A total of 135 participants (Table 5) completed the cognitive and attitude assessments (69 in the intervention and 66 in the control group, respectively), representing $46 \%$ of the total possible sample. A total of 128 participants (Table 5) completed food diaries (64 in the intervention and 65 in the control groups respectively), representing $44 \%$ of the possible sample. 
Table 4 Characteristics of schools

\begin{tabular}{|c|c|c|c|c|c|c|}
\hline School & School roll & Denomination & Number of free school dinners served & Size of Year 2 & Size of Year 7 & Group \\
\hline A & 251 & Roman Catholic & $36(14 \%)$ & 28 & 32 & Intervention \\
\hline $\mathrm{B}$ & 234 & Roman Catholic & $80-90 *(36 \%)$ & 29 & 36 & Control \\
\hline $\mathrm{C}$ & 260 & Non-denominational & $80-90(33 \%)$ & 48 & 50 & Intervention \\
\hline $\mathrm{D}$ & 230 & Non-denominational & $90(39 \%)$ & 31 & 40 & Control \\
\hline
\end{tabular}

* Reviewed 6 weekly.

\section{Cognitive and attitudinal assessments}

Table 6 summarises significant findings of the cognitive and attitudinal variables where there were differences between intervention and control groups over time. Children in the intervention group tasted more $\mathrm{F} \& \mathrm{~V}$ items over time than did children from the control group $(P<0.001)$. At the end of the study period, the intervention group reported having tasted several F\&V that had not been tasted at baseline (e.g. turnips, pineapple).

Understanding of the concept 'healthy' altered significantly $(P=0.002)$ with time in the intervention group, with clear identification of concepts such as strength, healthy heart and energy emerging from their answers. Both age groups were reasonably competent at categorising F\&V, although the scores for knowledge of paired choices (healthier options) was significantly greater in the intervention group than in the controls. The subjective norm (perceived social pressure) scores indicate that increased awareness of social pressure became greater in the intervention rather than the control group $(P=0.021)$.

Using the facial hedonic scales, children in the intervention group reported decreasing preference for the foods/drinks in the high-fat or higher sugar category. The intervention group chose fewer high-fat or high-sugar options in their top five favourites at T2 (as compared with T1), whilst in the control group ranked preferences remained constant $(P=0.042)$.

\section{Food and nutrients}

The weight of fruit intake increased in both intervention $(+50 \mathrm{~g})$ and control groups $(+7 \mathrm{~g})$, and was significantly $(P=0.042)$ greater in the intervention group. Vegetable intake showed no significant change in intervention $(-17 \mathrm{~g})$ or control groups $(-15 \mathrm{~g})$ (Table 7$)$.

In boys, the changes between $\mathrm{T} 1$ and $\mathrm{T} 2$ in the intervention and control groups were not significant for fruit (122 to $141 \mathrm{~g}$ in the intervention group, 94 to $108 \mathrm{~g}$ in the control group), vegetables ( 74 to $47 \mathrm{~g}$ in the intervention group, 75 to $54 \mathrm{~g}$ in the control group) and total F\&V (196 to $189 \mathrm{~g}$ in the intervention group, 169 to $163 \mathrm{~g}$ in the control group).

In girls, the change between $\mathrm{T} 1$ and $\mathrm{T} 2$ in the intervention and control groups was significant $(P=0.02)$ for fruit (141 to $216 \mathrm{~g}$ in the intervention group, 106 to $106 \mathrm{~g}$ in the control group). Differences in intakes of vegetables ( 65 to $56 \mathrm{~g}$ in the intervention group, 65 to $56 \mathrm{~g}$ in the control group) and in total F\&V
(207 to $272 \mathrm{~g}$ in the intervention group, 171 to $163 \mathrm{~g}$ in the control group) were not significant.

The range of fruits consumed increased in the intervention group but remained constant in the control group. The range of vegetables consumed decreased in both groups; the frequency of consumption and portion size are presented in Table 8. This undoubtedly reflects seasonal choices, with indications for future promotional work. There were no significant changes in macronutrient intakes between T1 and T2 (Table 9).

\section{Discussion}

Overall, these findings suggest that the intervention was delivered successfully. The results are generally consistent with studies in US schools ${ }^{27-31}$, which have shown significant increases in fruit intake and (with one exception $^{29}$ ) little impact on vegetable intake. In these US projects, interventions have been associated with increases of around $0.5 \mathrm{~F} \& \mathrm{~V}$ portions per day ${ }^{31}$, ranging from 0.2 (California) to 0.6 (Minnesota) servings. Commentators have concluded that the interventions

Table 5 Respondents participating in assessments

\begin{tabular}{|c|c|c|c|c|}
\hline \multirow[b]{2}{*}{ Assessment/school } & \multirow[b]{2}{*}{ Number } & \multirow{2}{*}{$\begin{array}{l}\text { Age (years), } \\
\text { mean } \pm S E\end{array}$} & \multicolumn{2}{|c|}{$\begin{array}{c}\text { Depcat score* } \\
\text { based on post } \\
\text { code }(\%)\end{array}$} \\
\hline & & & $1-3$ & $4-6$ \\
\hline \multicolumn{5}{|c|}{ Cognitive and attitudinal assessments } \\
\hline \multicolumn{5}{|l|}{ Intervention } \\
\hline Males & 31 & $8.10 \pm 0.49$ & 17 & 83 \\
\hline Females & 38 & $8.00 \pm 2.48$ & 14 & 86 \\
\hline Total & 69 & $8.04 \pm 2.55$ & 16 & 84 \\
\hline \multicolumn{5}{|l|}{ Control } \\
\hline Males & 32 & $7.72 \pm 2.52$ & 15 & 85 \\
\hline Females & 34 & $9.12 \pm 2.33$ & 6 & 94 \\
\hline Total & 66 & $8.44 \pm 2.53$ & 10 & 90 \\
\hline \multicolumn{5}{|l|}{ Food diaries } \\
\hline \multicolumn{5}{|l|}{ Intervention } \\
\hline Males & 28 & $8.4 \pm 2.28$ & 21 & 79 \\
\hline Females & 36 & $8.5 \pm 2.19$ & 22 & 78 \\
\hline Total & 64 & $8.4 \pm 2.21$ & 22 & 78 \\
\hline \multicolumn{5}{|l|}{ Control } \\
\hline Males & 31 & $8.1 \pm 2.11$ & 13 & 87 \\
\hline Females & 34 & $9.2 \pm 2.23$ & 12 & 88 \\
\hline Total & 65 & $8.6 \pm 2.23$ & 12 & 88 \\
\hline
\end{tabular}

SE - standard error.

*Depcat scores categorise deprivation category ${ }^{26}$ : 4-6, most deprived; $1-3$, least deprived. 
Table 6 Scores for cognitive and attitudinal variables in intervention $(n=69)$ and control $(n=66)$ groups

\begin{tabular}{|c|c|c|c|c|}
\hline \multirow[b]{2}{*}{ Description of measure } & \multirow[b]{2}{*}{ Total possible score } & \multicolumn{2}{|c|}{ Score, mean \pm SE } & \multirow{2}{*}{$\begin{array}{l}\text { Significant differences } \\
\text { between groups } \times \text { time }\end{array}$} \\
\hline & & T1 & $\mathrm{T} 2$ & \\
\hline Number of foods tasted & 32 & & & 0.001 \\
\hline Intervention & & $22.4 \pm 0.7$ & $27.0 \pm 0.6$ & \\
\hline Control & & $24.3 \pm 0.7$ & $25.0 \pm 0.8$ & \\
\hline Understanding of the concept 'healthy' & 10 & & & 0.002 \\
\hline $\begin{array}{l}\text { Intervention } \\
\text { Control }\end{array}$ & & $\begin{array}{l}3.8 \pm 0.3 \\
3.5 \pm 0.2\end{array}$ & $\begin{array}{l}5.4 \pm 0.2 \\
4.2 \pm 0.3\end{array}$ & \\
\hline Diet and heart disease knowledge & 3 & & & 0.001 \\
\hline Intervention & & $1.8 \pm 0.1$ & $2.4 \pm 0.1$ & \\
\hline Control & & $2.0 \pm 0.1$ & $2.2 \pm 0.1$ & \\
\hline Categorisation & 25 & & & 0.002 \\
\hline Intervention & & $20.3 \pm 0.5$ & $22.4 \pm 0.4$ & \\
\hline Control & & $19.9 \pm 0.6$ & $21.1 \pm 0.6$ & \\
\hline Subjective norm & 12 & & & 0.021 \\
\hline Intervention & & $9.5 \pm 0.3$ & $10.8 \pm 0.2$ & \\
\hline Control & & $9.5 \pm 0.3$ & $10.3 \pm 0.3$ & \\
\hline Preferences (displayed on hedonic scale) $\dagger$ & 30 & & & 0.034 \\
\hline $\begin{array}{l}\text { Intervention } \\
\text { Control }\end{array}$ & & $24.4 \pm 0.4$ & $23.5 \pm 0.5$ & \\
\hline Control & & $24.9 \pm 0.4$ & $24.7 \pm 0.4$ & \\
\hline Ranked preferences & 5 & & & 0.042 \\
\hline Intervention & & $2.5 \pm 2.0$ & $2.1 \pm 0.2$ & \\
\hline Control & & $2.7 \pm 2.8$ & $2.7 \pm 0.2$ & \\
\hline
\end{tabular}

SE - standard error; T2 measures made 9 months after T1 baseline measures.

${ }^{*}$ Non-significant findings are not reported; all variables are listed in Table 2.

†Differences relate to reduced preferences for high-sugar and high-fat snacks, not increased preferences for fruits and vegetables.

are probably successful at 'mitigating an age-related decline in consumption,29.

It is important to note that the short intervention period ( 9 months) cannot be used to demonstrate life-long changes in eating habits, but does show the ability of an education programme to impact on diet at a crucial life stage when eating habits are being formed. All the responses are reported intakes and have not been independently validated. These results are therefore comparable with other studies using similar methods, but are less robust than those from studies that examined independent markers

Table 7 Mean daily weight* of fruit, vegetables, and fruits and vegetables (F\&V) consumed as measured by 3 -day food diaries in intervention $(n=64)$ and control groups $(n=65)$

\begin{tabular}{lccc}
\hline & \multicolumn{2}{c}{ Weight $(\mathrm{g})$, mean $\pm \mathrm{SE}$} & $\begin{array}{c}\text { Intervention effect } \\
(P \text {-value })\end{array}$ \\
\cline { 2 - 3 } Variable & $\mathrm{T} 1$ & $\mathrm{~T} 2$ & 0.042 \\
\hline $\begin{array}{l}\text { Fruit } \\
\quad \text { Intervention }\end{array}$ & $133 \pm 11.9$ & $183 \pm 17.0$ & \\
$\quad$ Control & $100 \pm 11.7$ & $107 \pm 14.2$ & 0.823 \\
$\begin{array}{l}\text { Vegetables } \\
\quad \text { Intervention }\end{array}$ & $69 \pm 41.1$ & $52 \pm 48.6$ & \\
$\quad$ Control & $70 \pm 58.1$ & $55 \pm 42.3$ & \\
$\begin{array}{l}\text { F\&V } \\
\quad \text { Intervention }\end{array}$ & $202 \pm 101.9$ & $235 \pm 151.2$ & 0.617 \\
$\quad$ Control & $170 \pm 109.6$ & $163 \pm 109.6$ & \\
\hline
\end{tabular}

SE - standard error; T2 measures made 9 months after T1 baseline measures.

*The mean daily weights include conversions for fruit juice (dividing by a factor of 2.5) and for vegetable soups to include only vegetable content. †The value shown is the significance of the difference in change in intake from $\mathrm{T} 1$ to $\mathrm{T} 2$ between the intervention and control groups. of dietary change (e.g. plasma vitamin C or other nutrients found in high quantities in fruits).

In a project aimed wholly at outcome evaluation, the results should be measured at the school level, not at the individual pupil level. However, such an approach would not have facilitated the development of the programme and ongoing process evaluations. Sample size of 60 in each of the intervention and control arms was estimated to be able predict with $80 \%$ confidence a modest increase in intake of F\&V (e.g. rising from 200 to $230 \mathrm{~g}$ ).

Specific foods that had not been tasted before the intervention were subsequently tried as a direct function of the intervention. It is understood from the work of Birch et al. ${ }^{32}$ that mere exposure to some foods can lead to an enhancement or acceptance of similar food types. Therefore, the direct effect of the intervention in increasing the likelihood of tasting new $\mathrm{F} \& \mathrm{~V}$ may help towards developing a practical interest in tasting other F\&V. In a UK school-based study, improvements in preference and acceptance of $\mathrm{F} \& \mathrm{~V}$ were obtained by Horne et al. when using compulsory, daily exposure ${ }^{33}$.

The results for nutrient intake are similar to those reported by Gregory et al. ${ }^{7}$, suggesting that overall food intakes were fairly typical for children of this age.

One of the major challenges in any child-oriented project is getting parents involved. In the USA, work by Baranowski et $a l .{ }^{29}$ highlights that 'impacting on home consumption practices remain[s] elusive'. Future work could usefully consider how the challenge of parental involvement might be addressed. 
Table 8 Top 10 vegetables in terms of frequency of consumption by the intervention group

\begin{tabular}{|c|c|c|c|c|c|c|}
\hline \multicolumn{3}{|c|}{ T1 } & \multirow[b]{2}{*}{ Food } & \multicolumn{3}{|c|}{ T2 } \\
\hline Frequency & Mean portion (g) & Rank & & Rank & Mean portion (g) & Frequency \\
\hline 56 & 103 & 1 & Baked beans & 6 & 95 & 22 \\
\hline 29 & 45 & 2 & Carrots & 5 & 42 & 27 \\
\hline 28 & 39 & 3 & Tomatoes & 1 & 34 & 34 \\
\hline 24 & 49 & 4 & Sweet corn & 2 & 51 & 31 \\
\hline 24 & 52 & 5 & Peas & 7 & 56 & 22 \\
\hline 21 & 21 & 6 & Lettuce & 4 & 13 & 29 \\
\hline 15 & 28 & 7 & Cucumber & 3 & 32 & 30 \\
\hline 15 & 13 & 8 & Pepper & 10 & 22 & 4 \\
\hline 12 & 16 & 9 & Mushrooms & 12 & 27 & 3 \\
\hline 12 & 18 & 10 & Onion & 15 & 25 & 2 \\
\hline 6 & 55 & 15 & Broccoli & 8 & 54 & 7 \\
\hline 10 & 53 & 12 & Coleslaw & 9 & 59 & 6 \\
\hline
\end{tabular}

T2 measures made 9 months after T1 baseline measures.

Increasing vegetable intake in all ages across all social classes is probably the greatest challenge to nutrition educators. Increased provision of vegetables through the introduction of new nutrient standards for school lunches in Scotland ${ }^{34}$ will be viewed with interest.

Finally, the cost-effectiveness of this study is hard to estimate. The actual capital and development costs were around $£ 378$ (not necessary for widespread transfer) plus consumable costs of around $£ 13.50$ per school plus staff time over the entire 9-month period. The benefits were related not only to dietary change, but also contributed to general education, good school-home relations (through newsletters) and the general promotion of the integrated school involving pupils, staff (all grades) and parents.

Table 9 Mean daily macronutrient intakes

\begin{tabular}{|c|c|c|c|}
\hline \multirow[b]{2}{*}{ Variable } & \multicolumn{2}{|c|}{ Intake, mean $\pm \mathrm{SE}$} & \multirow{2}{*}{$\begin{array}{l}\text { Intervention effect } \\
\quad(P \text {-value })^{\star}\end{array}$} \\
\hline & $\mathrm{T} 1$ & T2 & \\
\hline $\begin{array}{l}\text { Energy }(\mathrm{kJ}) \\
\text { Intervention } \\
\text { Control }\end{array}$ & $\begin{array}{l}7922 \pm 207 \\
8268 \pm 257\end{array}$ & $\begin{array}{l}7926 \pm 213 \\
7920 \pm 236\end{array}$ & 0.327 \\
\hline $\begin{array}{l}\% \text { Energy as f } \\
\text { Intervention } \\
\text { Control }\end{array}$ & $\begin{array}{l}\text { at } \\
35.4 \pm 0.0065 \\
36.9 \pm 0.0051\end{array}$ & $\begin{array}{l}34.9 \pm 0.0056 \\
36.3 \pm 0.0063\end{array}$ & 0.929 \\
\hline $\begin{array}{l}\text { \% Energy as c } \\
\text { Intervention } \\
\text { Control }\end{array}$ & $\begin{array}{l}\text { arbohydrate } \\
51.3 \pm 0.0066 \\
49.8 \pm 0.0060\end{array}$ & $\begin{array}{l}51.8 \pm 0.0053 \\
51.2 \pm 0.0062\end{array}$ & 0.368 \\
\hline $\begin{array}{l}\% \text { Energy as } p \\
\text { Intervention } \\
\text { Control }\end{array}$ & $\begin{array}{l}\text { rotein } \\
13.1 \pm 0.0029 \\
13.0 \pm 0.0028\end{array}$ & $\begin{array}{l}13.1 \pm 0.0028 \\
12.2 \pm 0.0030\end{array}$ & 0.097 \\
\hline $\begin{array}{l}\text { Starch }(\mathrm{g}) \\
\text { Intervention } \\
\text { Control }\end{array}$ & $\begin{array}{l}128 \pm 4.4 \\
131 \pm 4.5\end{array}$ & $\begin{array}{l}131 \pm 4.0 \\
134 \pm 4.3\end{array}$ & 0.980 \\
\hline $\begin{array}{l}\text { Sucrose }(\mathrm{g}) \\
\text { Intervention } \\
\text { Control }\end{array}$ & $\begin{array}{l}55.1 \pm 17.5 \\
56.7 \pm 20.0\end{array}$ & $\begin{array}{l}54.6 \pm 19.4 \\
52.7 \pm 22.7\end{array}$ & 0.578 \\
\hline
\end{tabular}

SE - standard error; T2 measures made 9 months after T1 baseline measures.

* The value shown is the significance of the difference in change in intake from $\mathrm{T} 1$ to $\mathrm{T} 2$ between the intervention and control groups from a multiple regression model which included age and sex.
In conclusion, a novel, whole school intervention implemented over one academic year was associated with changes in knowledge, attitudes and practices relating to F\&V consumption.

\section{Acknowledgements}

We are grateful to Dundee City Council for all assistance with this project and DC Thomson \& Co. Ltd for permission to use The Bash Street Kids ${ }^{\circledR}$ graphics. The study was funded by The Food Standards Agency (UK) under its Food Acceptability and Choice R\&D Programme.

\section{References}

1 World Health Organization (WHO). Diet, Nutrition and the Prevention of Chronic Diseases. Geneva: WHO, 2003.

2 Ness AR, Powles JW. Fruit and vegetables, and cardiovascular disease: a review. International Journal of Epidemiology 1997; 26: 1-13.

3 Key TJ, Allen NE, Spencer EA, Travis RC. The effect of diet on risk of cancer. Lancet 2002; 360: 861-8.

4 Byers T, Nestle M, McTiernan A, Doyle C, Currie-Williams A, Gansler T, et al. American Cancer Society 2001 Nutrition and Physical Activity Guidelines Advisory Committee. American Cancer Society guidelines on nutrition and physical activity for cancer prevention: reducing the risk of cancer with healthy food choices and physical activity. CA: Cancer Journal for Clinicians 2002; 52: 92-119.

5 Havas S, Heimendinger J, Reynolds K, Baranowski T, Nicklas TA, Bishop D, et al. 5 a day for better health: a new research initiative. Journal of the American Dietetic Association 1994; 94: 32-6.

6 Department of Health. The NHS Cancer Plan. London: The Stationery Office, 2000.

7 Gregory J, Lowe S, Bates CJ, Prentice A, Jackson LV, Smithers G, et al. National Diet and Nutrition Survey: Young People aged 4 to 18 Years. Vol. 1. Report of the Diet and Nutrition Survey. London: The Stationery Office, 2000.

8 Wright CM, Parker L, Lamont D, Craft AW. Implications of childhood obesity for adult health: findings from the thousand families cohort study. British Medical Journal 2001; 323: 1280-4.

9 Birch LL. Development of food preferences. Annual Review of Nutrition 1999; 19: 41-62. 
10 Wardle J, Cooke LJ, Gibson EL, Sapochnik M, Sheiham A, Lawson M. Increasing children's acceptance of vegetables; a randomized trial of parent-led exposure. Appetite 2000; 40 : 155-62.

11 Lytle L, Achterberg C. Changing the diet of America's children: what works and why? Journal of Nutrition Education 1995; 27: 250-60.

12 Young IM. Health eating policy in schools: an evaluation of effects on pupils' knowledge, attitude and behaviour. Health Education Journal 1993; 52: 3-9.

13 http://www.foodstandards.gov.uk/interactivetools/ educational/bashstreetdiet/

14 Ajzen I, Fishbein M. Understanding Attitudes and Predicting Social Behaviour. Englewood Cliffs, NJ: Prentice Hall, 1980.

15 Birch LL, Zimmerman SI, Hind H. The influence of social affective context on the formation of children's food preferences. Child Development 1980; 51: 856-61.

16 Holland B, Welch AA, Unwin ID, Buss DH, Paul AA, Southgate DAT. McCance \& Widdowson's The Composition of Foods, 5 th ed. Royal Society of Chemistry and Ministry of Agriculture, Fisheries and Food. London: HMSO, 1995.

17 Holland B, Unwin ID, Buss DH. Cereals and Cereal Products. Third Supplement to McCance \& Widdowson's The Composition of Foods, 4th ed. Royal Society of Chemistry and Ministry of Agriculture, Fisheries and Food. London: HMSO, 1988.

18 Holland B, Unwin ID, Buss DH. Milk Products and Eggs. Fourth Supplement to McCance \& Widdowson's The Composition of Foods, 4th ed. Royal Society of Chemistry and Ministry of Agriculture, Fisheries and Food. London: HMSO, 1989.

19 Holland B, Unwin ID, Buss DH. Vegetables, Herbs and Spices. Fifth Supplement to McCance \& Widdowson's The Composition of Foods, 4th ed. Royal Society of Chemistry and Ministry of Agriculture, Fisheries and Food. London: HMSO, 1991.

20 Holland B, Unwin ID, Buss DH. Fruit and Nuts. First Supplement to McCance \& Widdowson's The Composition of Foods, 5th ed. Royal Society of Chemistry and Ministry of Agriculture, Fisheries and Food. London: HMSO, 1992.

21 Holland B, Welch AA, Buss DH. Vegetable Dishes: Second Supplement to McCance \& Widdowson's The Composition of Foods, 5th ed. Royal Society of Chemistry and Ministry of Agriculture, Fisheries and Food. London: HMSO, 1992.

22 Holland B, Brown J, Buss DH. Fish and Fish Products. Third Supplement to McCance \& Widdowson's The Composition of Foods, 5th ed. Royal Society of Chemistry and Ministry of Agriculture, Fisheries and Food. London: HMSO, 1993.
23 Chan W, Brown J, Buss DH. Miscellaneous Foods. Fourth Supplement to McCance \& Widdowson's The Composition of Foods, 5th ed. Royal Society of Chemistry and Ministry of Agriculture, Fisheries and Food. London: HMSO, 1994.

24 Chan W, Brown J, Lee SJ, Buss DH. Meat Poultry and Game. Fifth Supplement to McCance \& Widdowson's The Composition of Foods, 5 th ed. Royal Society of Chemistry and Ministry of Agriculture and Fisheries and Food. London: HMSO, 1995.

25 Chan W, Brown J, Church SM, Buss DH. Meat Products and Dishes. Sixth Supplement to McCance \& Widdowson's The Composition of Foods, 5th ed. Royal Society of Chemistry and Ministry of Agriculture, Fisheries and Food. London: HMSO, 1996.

26 Carstairs V, Morris R. Deprivation and Health in Scotland. Aberdeen: Aberdeen University Press, 1991.

27 Nicklas TA, Johnson CC, Myers L, Farris RP, Cunningham A. Outcomes of a high school program to increase fruit and vegetable consumption: Gimme 5 - a fresh nutrition concept for students. Journal of School Health 1998; 68 : 248-53.

28 Perry CL, Bishop D, Taylor G, Murray D, Mays RW, Dudovitz BS, et al. Changing fruit and vegetable consumption among children: The 5 A Day Power Plus programme in St Paul, Minnesota. American Journal of Public Health 1998; 88: 603-9.

29 Baranowski T, Davis M, Resnicow K, Baranowski J, Doyle C, Lin LS, et al. Gimme 5 fruit, juice, and vegetables for fun and health: outcome evaluation. Health Education \& Behavior 2000; 27: 96-111.

30 Reynolds KD, Franklin FA, Binkley D, Raczynski JM, Harrington KF, Kirk KA, et al. Increasing the fruit and vegetable consumption of fourth-graders: results from the high 5 project. Preventive Medicine 2000; 4: 309-19.

31 Agency for Healthcare Research and Quality. Efficacy of Interventions to Modify Dietary Behavior Related to Cancer Risk [online], 2001. Available at http://www.ahrq.gov/clinic/ epcsums/dietsumm.htm

32 Birch LL, McPhee L, Shoba BC, Pirok E, Steinberg L. What kind of exposure reduces children's neophobia? Appetite 1987; 9: 171-8.

33 Horne PJ, Lowe CF, Fleming PF, Dowey AJ. An effective procedure for changing food preferences in 5-7-year-old children. Proceedings of the Nutrition Society 1995; 54: $441-52$.

34 Scottish Executive. Hungry for Success - A Whole School Approach to School Meals. Edinburgh: The Stationery Office, 2000 . 